\title{
THE EFFECT OF FINANCIAL COMPENSATION ON EMPLOYEE PERFORMANCE AT PT. BANK BTPN CABANG SUNGGUMINASA KABUPATEN GOWA
}

\author{
Eka Pradila Putra
}

Ekonomi Dan Bisnis Universitas Muhammadiyah Makassar

\section{ARTICLEINFO}

Keywords: Compensation, Employee Performance

Email:

ekapradila10@gmail.com

\begin{abstract}
Financial compensation is one of several factors that can affect the level of employee performance. Compensation is an addition to the basic salary that is not expected by employees, but only part of it can be given, but only has certain achievements or certain skills and does not rebel when asked to complete it as soon as possible, such as reports or receipts that must be reported. This research was conducted using simple linear regression analysis, $\mathrm{f}$ test and test to analyze the close relationship of 1 variable. The purpose of this study was to determine the effect of financial compensation on employee performance at PT. Bank BTPN Sungguminasa branch, Gowa Regency.
\end{abstract}

Copyright (C) 2021 Journal of Economics.All rights reserved. is Licensed under a Creative Commons Attribution-NonCommercial 4.0 International License (CC BY-NC 4.0)

\section{INTRODUCTION}

PT. Bank Btpn Sungguminasa Branch, Gowa Regency, in the concept of management, humans are expected to be able to utilize the workforce fully or optimally to increase work productivity, which is followed by the creation of a relationship of full quality and responsibility and mutual building. Utilization of these human resources and skilled in their respective fields contain understandings of the structure and development of the quality of the workforce related to the development of Human Resources, both actual and potential.[1], [2].

The issue of labor compensation has become a national problem since the eighties. In the effort to increase work productivity, it is discussed everywhere and it is recommended that 1996 be the year of national productivity[3], [4]. Increasing employee productivity is the responsibility of every company. Through the leaders, this agency tries its best and in various ways to further maximize the potential of employees to achieve the goals that have been determined[5].

Regarding the increase in employee productivity, it is not a monopoly of this agency, which is only looking for profit, but also in the interests of organizations that sell their services to the public.[6]. Overcoming a growing problem that must be faced today is that there are no qualification standards for certain skills, making it very difficult to find suitable manpower to fill available vacancies. [7], [8].

PeTo solve this problem, a leader or part of the main leadership, the personnel manager, needs to understand the meaning and functions of Human Resource management, to gain effectiveness and efficiency in the company in utilizing a proportional workforce. It is clear that the use of human resources in increasing productivity is a system problem, because many aspects of work and office activities have an impact on increasing productivity.[9], [10].

\section{METHOD}

\section{Place and time of research}

This research was conducted in Gowa Regency, South Sulawesi, where PT. BANK BTPN Sungguminasa Branch, Gowa Regency was used as the object of research. Meanwhile, the time of research and preparation of reports started from March to May.

The Effect Of Financial Compensation On Employee Performance At Pt. Bank Btpn Cabang Sungguminasa Kabupaten Gowa Eka Pradila Putra 
http://ejournal.seaninstitute.or.id/index.php/Ekonomi

Jurnal Ekonomi, Volume 10, No 02 December 2021

ISSN: 2301-6280 (print) ISSN: 2721-9879 (online)

\section{Data Collection}

To collect the data and information needed in this research, the case study method is used and the data is collected through research, as follows:

1. Pelibrary research, namely research conducted by conducting a direct study of several books (library materials), and scientific essays that are closely related to the problems discussed.

2. Pefield research, namely research carried out by conducting direct visits to the research place that has been determined.

To collect the required field data, the following techniques/methods are used: Observation, namely making direct observations of the research site.

\section{Data Types and Sources}

JeThe types of data needed in this research are sourced from:

1. Jenis Quantitative data, namely data obtained from the office under study in the form of numbers.

2. Ssource data

Ssources of data in this study, including:

a. Primary data, namely data obtained directly from the company through observation and interviews.

b. Secondary data, namely data sourced from the company in the form of documentation and written reports that are made periodically.

\section{metode Analysis}

To test the hypothesis proposed in this study, the following analytical methods were used

1. Descriptive analysis method, which explains the type of financial compensation provided by the company to employees.

2. The comparative method is to compare the performance before and after receiving financial compensation.

3. Analysis of the effectiveness of how much liquid target occurs or does not increase

4. Regression analysis.

TeThe data analysis technique used in this research is simple linear regression analysis (Simple Linear Regression). This analysis is used in production to forecast or predict the characteristics of quality and quantity.

$\mathrm{Y}=$ response variable or effect variable (dependent)

$$
\mathrm{Y}=\mathrm{a}+\mathrm{bX}
$$

$\mathrm{X}=$ predictor variable or causal factor variable (independent)

$\mathrm{a}=$ constant

$\mathrm{b}=$ regression coefficient (slope); the magnitude of the response generated by the predictor.

\section{RESULTS AND DISCUSSION}

\section{Respondent Description}

PeThis study describes the effect of financial compensation to improve the performance of employees of PT. BANK BTPN Sungguminasa Branch, Gowa Regency. This aims to determine how much influence financial compensation can improve employee performance at PT. BANK BTPN Sungguminasa Branch, Gowa Regency. In this study, using 32 employees as research samples. Characteristics of respondents are useful to describe the description of the identity of the respondents according to the research sample that has been determined. One of the objectives with the characteristics of the respondents is to provide an overview of the sample in this study. The characteristics of the respondents who were sampled in this study were then grouped according to age, gender, rank, education level, and years of service.

Age

Table 1

KCharacteristics of Respondents Based on Age

\begin{tabular}{cccc}
\hline No & Umur & \multicolumn{2}{c}{$\begin{array}{c}\text { frequencythe answer } \\
\text { Respondent }\end{array}$} \\
\cline { 3 - 4 } & & Person & Prepercentage \\
\hline 1 & $25-31$ & 16 & $50.0 \%$ \\
2 & $34-38$ & 8 & $25.0 \%$ \\
3 & $40-50$ & 8 & $25.0 \%$ \\
\hline
\end{tabular}


http://ejournal.seaninstitute.or.id/index.php/Ekonomi

Jurnal Ekonomi, Volume 10, No 02 December 2021

ISSN: 2301-6280 (print) ISSN: 2721-9879 (online)

Jumlah

32

$100 \%$

From table 1 above, from 32 respondents, age grouping is labeled with age group 1 (25-32 years) which results are 16 people or $50.0 \%$. Age group 2 (34-38 years) as many as 8 people or $25.5 \%$. Age group 3 ( $40-50$ years) as many as 8 people or $25.5 \%$.

\section{Gender}

Table 2.

Characteristics of Respondents Based on Gender

\begin{tabular}{cccc}
\hline No & Gender & \multicolumn{2}{c}{$\begin{array}{c}\text { frequencythe answer } \\
\text { Respondent }\end{array}$} \\
\cline { 3 - 4 } & & Person & Prepercentage \\
\hline 1 & Male & 20 & $62.5 \%$ \\
2 & Woman & 12 & $37.5 \%$ \\
\hline & Jumlah & 32 & $100 \%$
\end{tabular}

Based on data processing using SPSS 20 software, table 2 above shows that of the 32 respondents, most of them were male, namely 20 people or $62.5 \%$ and the rest were female respondents as many as 12 people or $37.5 \%$. Rank

Table 3

Characteristics of Respondents by Rank

\begin{tabular}{cccc}
\hline No & group & \multicolumn{2}{c}{ Frequency of Respondents' Answers } \\
\cline { 3 - 4 } & & Person & Percentage \\
\hline 1 & $5-9$ & 29 & $90.6 \%$ \\
2 & $11-13$ & 3 & 9.4 \\
\hline & Amount & 32 & $100 \%$ \\
\hline
\end{tabular}

BerdaBased on table 3 above, it describes the rank group, the rank group 5-9 is 29 people (90.6\%), and the group $11-13$ is 3 people $(9.4 \%)$.

Pendikan

Table 4

KCharacteristics of Respondents Based on Education

\begin{tabular}{cccc}
\hline No & Pendikan & \multicolumn{2}{c}{ frequencythe Respondent's Answer } \\
\cline { 3 - 4 } & & Person & Prepercentage \\
\hline 1 & D3 & 2 & $6.3 \%$ \\
2 & S1 & 27 & $84.4 \%$ \\
3 & S2 & 2 & $6.3 \%$ \\
4 & SMA & 1 & $3.1 \%$ \\
\hline
\end{tabular}

The results of data processing regarding the characteristics of respondents based on the level of education are shown in table 4 above, from 32 respondents there are 2 people or $6.3 \%$ who have D3 education. There are 27 people or $84.4 \%$ with $\mathrm{S} 1$ education. There are 2 people or $6.3 \%$ who have master's degree education. And there is 1 person or $3.1 \%$ who has a high school education.

hope to work

Table 5

KCharacteristics of Respondents Based on Years of Work

\begin{tabular}{cccc}
\hline \multirow{2}{*}{ No } & work hope & \multicolumn{2}{c}{ frequencythe Respondent's Answer } \\
\cline { 3 - 4 } & & Person & Prepercentage \\
\hline 1 & $1-8$ & 22 & $69 \%$ \\
2 & $10-30$ & 10 & $31 \%$
\end{tabular}

The Effect Of Financial Compensation On Employee Performance At Pt. Bank Btpn Cabang Sungguminasa Kabupaten Gowa Eka Pradila Putra 
http://ejournal.seaninstitute.or.id/index.php/Ekonomi

Jurnal Ekonomi, Volume 10, No 02 December 2021

ISSN: 2301-6280 (print) ISSN: 2721-9879 (online)

Jumlah

32

$100 \%$

The results of data processing regarding the characteristics of respondents based on respondent data in this study generally have a working period of $1-8$ as many as 22 people (69\%), and $10-30$ working years as many as 10 people (31\%).

Description of the Compensation Variable (X) and the Calculation of the Independent Variable Score.

To see the respondents' responses to the indicators that became the question items on the questionnaire and also the calculation of scores for the compensation variable $(\mathrm{X})$, as follows:

\section{Compensation Variable Statement (X)}

the indicators of this variable are divided into 5 statements. We can see the result as follows:

Table 6

Respondents Response Compensation (X1)

\begin{tabular}{|c|c|c|c|c|c|c|c|c|c|c|c|}
\hline \multirow{2}{*}{$\begin{array}{l}\text { Tassumption } \\
\text { Pstatement }\end{array}$} & \multicolumn{2}{|c|}{$\begin{array}{l}\text { Svery much } \\
\text { Sagree }\end{array}$} & \multicolumn{2}{|c|}{ Sagree } & \multicolumn{2}{|c|}{$\begin{array}{l}\text { Kshrimp } \\
\text { sagree }\end{array}$} & \multicolumn{2}{|c|}{ Til agree } & \multicolumn{2}{|c|}{$\begin{array}{c}\text { Sreally no } \\
\text { Sagree }\end{array}$} & \multirow[t]{2}{*}{ Skor } \\
\hline & $\mathrm{F}$ & $\%$ & $\mathrm{~F}$ & $\%$ & $\mathrm{~F}$ & $\%$ & $\mathrm{~F}$ & $\%$ & $\mathrm{~F}$ & $\%$ & \\
\hline $\mathrm{X} 1.1$ & 15 & 46.9 & 17 & 53.1 & 0 & 0 & 0 & 0 & 0 & 0 & 143 \\
\hline $\mathrm{X} 1.2$ & 5 & 15.6 & 16 & 50.0 & 7 & 21.9 & 4 & 12.5 & 0 & 0 & 118 \\
\hline $\mathrm{X} 1.3$ & & & & & & & & & & & \\
\hline & 15 & 46.9 & 14 & 43.8 & 3 & 9.4 & 0 & 0 & 0 & 0 & 140 \\
\hline & 4 & 12.5 & 13 & 40.6 & 8 & 25.0 & 7 & 21.9 & 0 & 0 & 110 \\
\hline & 12 & 37.5 & 13 & 40.6 & 2 & 6.3 & 5 & 15.6 & 0 & 0 & 128 \\
\hline
\end{tabular}

Average

127.8

From the data that has been processed in table 6 above, it can be concluded that the respondent's response to the compensation variable $(\mathrm{X})$, is positive by looking at the average of the total score on this variable question of 127.8 .

Description of the employee performance variable $(\mathrm{Y})$ and the calculation of the dependent variable score

IThe indicators of this variable are divided into 5 statements. We can see the result as follows:

Table 7

Respondents Response Employee Performance Variable (Y)

\begin{tabular}{|c|c|c|c|c|c|c|c|c|c|c|c|}
\hline \multirow{2}{*}{$\begin{array}{l}\text { Tassumption } \\
\text { Pstatement }\end{array}$} & \multicolumn{2}{|c|}{$\begin{array}{c}\text { Svery much } \\
\text { Sagree }\end{array}$} & \multicolumn{2}{|c|}{ Agree } & \multicolumn{2}{|c|}{ Doubtful } & \multicolumn{2}{|c|}{$\begin{array}{c}\text { Tidak } \\
\text { Sagree }\end{array}$} & \multicolumn{2}{|c|}{$\begin{array}{l}\text { Sreally no } \\
\text { Sagree }\end{array}$} & \multirow[t]{2}{*}{ Skor } \\
\hline & $\mathrm{F}$ & $\%$ & $\mathrm{~F}$ & $\%$ & $\mathrm{~F}$ & $\%$ & $\mathrm{~F}$ & $\%$ & $\mathrm{~F}$ & $\%$ & \\
\hline $\mathrm{Y} .1$ & 25 & 78.1 & 5 & 15.6 & 2 & 6.3 & 0 & 0 & 0 & 0 & 151 \\
\hline Y.2 & 10 & 31.3 & 15 & 46.9 & 6 & 18.8 & 1 & 3.1 & 0 & 0 & 130 \\
\hline \multicolumn{12}{|l|}{ Y.3 } \\
\hline \multicolumn{12}{|l|}{ Y.4 } \\
\hline & 21 & 65.6 & 10 & 31.3 & 10 & 31.1 & 0 & 0 & 0 & 0 & 148 \\
\hline & 26 & 81.3 & 5 & 15.6 & 1 & 3.1 & 0 & 0 & 0 & 0 & 153 \\
\hline \multicolumn{11}{|c|}{ Average } & 139.4 \\
\hline
\end{tabular}

The Effect Of Financial Compensation On Employee Performance At Pt. Bank Btpn Cabang Sungguminasa Kabupaten Gowa Eka Pradila Putra 
From the data that has been processed and presented in table 7 above, it can be concluded that the respondents' responses regarding employee performance arising from the consequences caused by the compensation variable (X1) are positive by looking at the average of the total scores on this question of 139.4 and greater than the range of variable scores $(\mathrm{x})$.

\section{MEASUREMENT OF RESEARCH INSTRUMENTS Validity test}

The validity test was conducted to determine the level of validity of each question item in the questionnaire (questionnaire). The validity test was carried out on all questions in the instrument, namely by correlating the score of each item with the total score for each construct. The correlation technique used is the tPearson product moment correlation with one-tailed test. The data was processed with the help of the SPSS 22 program and the complete calculation can be seen in the appendix.

Table 8 Validity test

\begin{tabular}{cccc}
\hline Itheme & $\begin{array}{c}\text { Pearson } \\
\text { Correlation }\end{array}$ & RTabel & Description \\
\hline X1.1 & 0.407 & 0.349 & Valid \\
X1.2 & 0.721 & 0.349 & Valid \\
X1.3 & 0.437 & 0.349 & Valid \\
X1.4 & 0.824 & 0.349 & Valid \\
X1.5 & 0.745 & 0.349 & Valid \\
& Pearson & & \\
Itheme & Correlation & RTabel & Description \\
Y.1 & 0.553 & 0.349 & Valid \\
Y.2 & 0.775 & 0.349 & Valid \\
Y.3 & 0.844 & 0.349 & Valid \\
Y.4 & 0.564 & 0.349 & Valid \\
Y.5 & 0.468 & 0.349 & Valid
\end{tabular}

Based on the table of validity test results above, it is known that all question items used in this study are valid, which is indicated by the value of each question item having a positive Pearson Correlation value and is greater than the Rtable value.

\section{Reliability Test}

The technique used to measure the level of reliability is Cronbach Alpha by comparing the Alpha value with the standard, provided that:

1. Cronbach Alpha 0.00 to 0.20 , meaning less reliable

2. Cronbach Alpha value 0.21 to 0.40 , meaning somewhat reliable

3. The Cronbach Alpha value is 0.42 to 0.60 , meaning it is quite reliable

4. Cronbach Alpha value 0.61 to 0.80 , means reliable

5. Cronbach Alpha value 0.81 to 1.00 , means very reliable

The table below shows the results of reliability testing using the SPSS 20.00 tool.

Table 9

Reliability Test Results

Variable Cronbhach's Alpha Cronbhach, Standard Keterwishful thinking

Alpha 


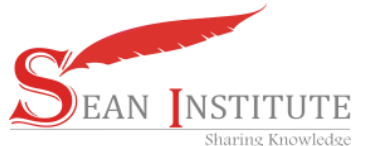

http://ejournal.seaninstitute.or.id/index.php/Ekonomi

Jurnal Ekonomi, Volume 10, No 02 December 2021

ISSN: 2301-6280 (print) ISSN: 2721-9879 (online)

\begin{tabular}{cccc}
\hline Compensation & 0.653 & 0.60 & Reliable \\
Employee performance & 0.668 & 0.60 & Reliable
\end{tabular}

Berdasuggest the table of reliability test results, fifteen variable items (questions) have an alpha coefficient greater than 0.60 . Based on the above provisions, the variables in this study are reliable.

\section{Coefficient of Determination Test R2}

The coefficient of determination ( R2) is a coefficient that shows the percentage influence of all independent variables. This percentage shows how big the independent variable (work discipline) is. The greater the coefficient of determination, the better the dependent variable in explaining the independent variable. To find out the magnitude of the influence of the independent variable, it can be seen in the following table.

Table 10

Coefficient of Determination Test

\begin{tabular}{ccccc}
\hline Model & $\mathrm{R}$ & $\mathrm{R}$ Square & Adjusted R Square & Std. Error of the Estimate \\
\hline 1 & $.541 \mathrm{a}$ & .293 & .269 & .39501 \\
\hline
\end{tabular}

The coefficient of determination above can be seen that the $\mathrm{R}$ Square value is 0.293 , which means that the effect of financial compensation on employee performance is $29.3 \%$ while the remaining $70.7 \%$ is influenced by other variables not included in this study.

\section{Partial Test ( T TEST )}

The t-test was conducted to determine the effect of each variable on the dependent variable individually. To answer the hypothesis that has been proposed by the t-test, the statistical hypotheses are:

Ho : there is no significant effect between work discipline variables on employee work productivity variables. $\mathrm{Ha}$ : there is a significant effect between work discipline variables on employee productivity variables.

The results of the t-test using the SPSS 20 program can be seen in the following table.

\section{tabell 11}

Output Coefficient X And Y

\begin{tabular}{cccccc}
\hline Model & \multicolumn{2}{c}{$\begin{array}{c}\text { Unstandardized } \\
\text { Coefficients }\end{array}$} & $\begin{array}{c}\text { Standardized } \\
\text { Coefficients }\end{array}$ & T & Sig. \\
\cline { 2 - 3 } & B & Std. Error & Beta & & \\
\hline $\begin{array}{c}\text { (Constant nt) } \\
1\end{array}$ & 2.527 & .524 & & 4.826 & .000 \\
COMPENSATION & .458 & .130 & .541 & 3.524 & .001
\end{tabular}

Based on the results of the t-test above, it is known that the regression coefficient value of the variable (X) or financial compensation is 0.458 so it can be said that the financial compensation variable (X) has a positive effect on employee performance by $45.8 \%$. From the results of the regression analysis, the $t$-count value was $3.524>\mathrm{t}$-table 2.042 and the significance value (sig.) was $0.001<0.005$. So it can be concluded that Ho is rejected and $\mathrm{Ha}$ is accepted, which means that compensation $(\mathrm{X})$ has a significant effect on employee performance.

Perthe regression equation is as follows: $\mathrm{Y}=\mathrm{b}\urcorner 0+\mathrm{bX}$

$\mathrm{Y}=2.527+0.458 \mathrm{X}$

BerdaBased on the regression equation, it can be concluded that there are other variables that affect employee performance outside of those studied by researchers.

\section{DISCUSSION}

Based on the results of the calculations and analysis above, the regression equation is obtained: $Y=2.527$ $+0.458 \mathrm{X}$ The regression equation can be concluded that there are other variables that affect employee performance outside of those studied by researchers at PT. Bank Btpn Gowa Branch, South Sulawesi Province. 
http://ejournal.seaninstitute.or.id/index.php/Ekonomi Jurnal Ekonomi, Volume 10, No 02 December 2021 ISSN: 2301-6280 (print) ISSN: 2721-9879 (online)

The results of the validity test can be seen that all rcount values are greater than rtable $n-2=30(0.349)$ at a significance level of 5\%. This means that each question item / variable indicator of work discipline and employee performance correlates with the total score and the data collected is declared valid and ready to be analyzed at PT. Bank Btpn Sungguminasa Branch, Gowa Regency. The results of the reliability test obtained a reliability coefficient value greater than 0.6 . In accordance with the statement, declared reliable (reliable) if the value of Cronbach's alpha is greater than 0.6 . So, it can be stated that all statements in the questionnaire are reliable (reliable).

Based on the coefficient of determination above, it can be seen that the R Square value is 0.293 , which means that the effect of compensation on employee performance is $29.3 \%$ while the remaining $70.7 \%$ is influenced by other variables not included in this study.

Based on the results of the t-test above, it is known that the value of the variable regression coefficient $(\mathrm{X})$ or compensation is 0.458 , so it can be said that the compensation variable $(\mathrm{X})$ has a positive effect on employee performance by $45.8 \%$. From the results of the regression analysis, the $\mathrm{t}$-count value was $3.524>\mathrm{t}$ table was 2.042 and the significance value (sig.) was $0.001<0.05$. So it can be concluded that Ho is rejected and $\mathrm{Ha}$ is accepted, which means that compensation $(\mathrm{X})$ has a significant effect on employee performance.

It is suspected that the existence of compensation has a significant effect on the performance of employees at PT. bank Btpn sunggumisa branch, gowa district. This means that the hypothesis is accepted, because together there is a positive relationship between compensation and employee performance at PT. bank Btpn sungguminasa branch, gowa district.

\section{CONCLUSION}

suggest the results of research on the effect of financial compensation on employee performance at PT. Bank Btpn Sungguminasa branch, Gowa Regency, South Sulawesi Province, it can be concluded that the compensation variable has a significant effect on employee performance. That is, the existence of employee obedience in the performance of employees of PT. Bank Btpn Sungguminasa Gowa Branch.

\section{Reference}

[1] M. P. Dra. Yuyu Hendawati, "Sumber Daya Alam Dan Lingkungan Hidup," Sumber Daya Alam Dan Lingkung. Hidup, 2012.

[2] I. N. Suryawan and K. Kunci, "MANAJEMEN EKOREGION MELALUI PEMBERDAYAAN DAN PEMELIHARAAN LINGKUNGAN HIDUP DALAM RANGKA MENINGKATKAN KESEJAHTERAAN MASYARAKAT (Suatu Tinjauan Tentang Green Economic)," MEDIA BISNIS, 2012.

[3] S. Hersona Dkk, "Analisis Pengaruh Pengembangan SDM Terhadap Kinerja Pegawai Pada Badan Kepegawaian Daerah Kabupaten Karawang," J. Manaj., 2012.

[4] H. Sonny, "Analisis Pengaruh Pengembangan SDM Terhadap Kinerja Pegawai Pada Badan Kepegawaian Daerah Kabupaten Karawang," J. Manaj., vol. 09, no. 3, 2012.

[5] Ni Putu Pradita Laksmiari, "Pengaruh Motivasi Kerja Terhadap Produktivitas Kerja Karyawan Pada Perusahaan Teh Bunga Teratai Di Desa Patemon Kecamatan Serrit," J. Pendidik. Ekon., vol. 10, no. 2, 2012.

[6] W. Bangun, "PENGARUH KARAKTERISTIK PEKERJAAN TERHADAP KEPUASAN KERJA DAN KOMITMEN ORGANISASI SERTA DAMPAKNYA PADA PRODUKTIVITAS KERJA KARYAWAN (Survai pada Karyawan Industri Tekstil Propinsi Jawa Barat)," CORE Sosiohumaniora, vol. 8, no. 2, 2012.

[7] Nur'aini, Faktor-faktor yang Mempengaruhi Produktivitas Kerja Karyawan Pada Perusahaan Roti Holland Bakery Pekanbaru. 2012.

[8] N. Fitriyanto, "Pengaruh Motivasi Kerja, Disiplin Kerja Dan Pengalaman Kerja Terhadap Produktivitas Kerja Karyawan Pada Industri Kerajinan Topeng Di Dusun Bobung Putat Patuk Kabupaten Gunungkidul," Fak. Ekon. > Pendidik. Ekon., 2012.

[9] R. Sari, N. L. Suryani, R. Setiawan, D. Darmadi, and N. Susanto, "PENGELOLAAN SUMBER DAYA MANUSIA DALAM MENINGKATKAN PRODUKTIVITAS PADA UKM KELURAHAN PAGEDANGAN KABUPATEN TANGGERANG-BANTEN," Dedik. PKM, vol. 1, no. 3, 2020, doi: 10.32493/dedikasipkm.v1i3.6751.

[10] R. W. Lestari, Pengaruh Upah, Tingkat Pendidikan dan Teknologi Terhadap Produktifitas Tenaga Kerja Pada Industri Kecap di Kecamatan Pati Kabupaten Pati. 2011. 
http://ejournal.seaninstitute.or.id/index.php/Ekonomi Jurnal Ekonomi, Volume 10, No 02 December 2021 ISSN: 2301-6280 (print) ISSN: 2721-9879 (online) 